\title{
PENGARUH LOKASI DAN STORE ATMOSPHERE TERHADAP KEPUTUSAN PEMBELIAN PADA WARUNG KOPI JAELANSKY PAMULANG
}

\author{
${ }^{1}$ Claudia Meliana Putri, ${ }^{2 *}$ Cornelia Dumarya Manik \\ Universitas Pamulang, Tangerang, Banten, Indonesia \\ *Cornelia00720@unpam.ac.id
}

\begin{abstract}
Abstrak
Tujuan penelitian ini adalah untuk mengetahui pengaruh Lokasi dan Store Atmosphere terhadap keputusan pembelian pada Warung Kopi Jaelansky Pamulang. Metode yang digunakan adalah metode asosiatif kuantitatif. Teknik sampling yang digunakan adalah random sampling menggunakan sampel sebanyak 99 responden. Analisis data menggunakan analisis regresi, analisis koefisien korelasi, analisis koefisien determinasi dan uji hipotesis. Hasil penelitian initerdapat pengaruh yang signifikan secara simultan antara Lokasi dan Store Atmosphere terhadap keputusan pembelian pada Warung Kopi Jaelansky Pamulang.
\end{abstract}

Kata Kunci : Lokasi, Store Atmosphere dan Keputusan Pembelian

Abstract

The purpose of this study was to determine the effect of Location and Store Atmosphere on purchase decisions at Warung Kopi Jaelansky Pamulang. The method used is quantitative associative method. The sampling technique used is random sampling using a sample of 99 respondents. Data analysis used regression analysis, correlation coefficient analysis, determination coefficient analysis and hypothesis testing. The results of this study has a simultaneous significant influence between the location and the store atmosphere on purchase decisions at Warung Kopi Jaelansky Pamulang.

Keywords : Location, Store Atmosphere and Purchase Decisions

\section{PENDAHULUAN}

Fenomena menjamurnya kedai kopi dimana tidak hanya sekadar aktivitas jual beli minuman kopi, tetapi kedai kopi disini menawarkan atmosfer yang berbeda dari sisi fasilitas dan kenyamanan tempat. Bahkan kedai kopi sudah bisa dikatakan sebagai rumah kedua untuk menghilangkan penat dan bersantai. Tingginya antusias kaum muda terhadap kedai kopi membuat maraknya kedai kopi di Indonesia khususnya di kota-kota besar.

Warung Kopi Jaelansky merupakan kedai kopi yang berada di wilayah Pamulang, Tangerang Selatan yang juga memanfaatkan peluang bisnis di bidang kopi. Namun, maraknya bisnis kedai kopi di Indonesia termasuk di Pamulang sendiri menyebabkan persaingan menjadi semakin ketat. Mengingat ketatnya persaingan dalam bisnis ini maka lokasi menjadi salah satu peranan penting dalam pemasaran.
Lokasi juga sangatlah mempengaruhi konsumen untuk datang dan memutuskan untuk membeli. Perusahaan harus menentukan lokasi yang strategis yang kemudian nantinya akan berdampak pada peningkatan penjualan. Lokasi dapat pula diartikan sebagai tempat untuk menawarkan barang sehingga konsumen dapat melihat langsung barang yang dijual sehingga konsumen dapat lebih mudah memilih dan bertransaksi atau melakukan pembelian yang ditawarkan secara langsung oleh karyawan yang bertugas.

Lokasi yang mudah dijangkau atau yang berada ditengah keramaian akan membuat pelanggan merasa bahwa mereka telah diperhatikan, apalagi jika dekat dengan fasilitas-fasilitas yang mendukung lainnya. Pemilihan lokasi mempunyai fungsi yang strategis karena dapat ikut menentukan tercapainya tujuan usaha. 
lokasi dan lokasi dari Warung Kopi Jaelansky diatas dapat dilihat bahwa pemilihan lokasi sangatlah tidak strategis karena posisinya berada didalam komplek Pasar Kita Pamulang yang tertutup dan jarang dilalui orang karena bukan merupakan jalan besar. Warung Kopi Jaelansky juga berada di lingkungan yang banyak terdapat kedai kopi sejenis dimana kompetitor atau pesaingnya cukup ketat sehingga menyebabkan pelanggan tidak hanya berfokus pada Warung Kopi Jaelansky saja.

Selain lokasi, suatu kedai terlebih kedai kopi juga harus membentuk suasana terencana yang baik dan sesuai dengan pasar sasarannya sehingga dapat menarik pelanggan untuk membeli di kedai tersebut. Store Atmosphere atau suasana toko merupakan suatu karakteristik fisik yang sangat penting, hal ini berperan sebagai penciptaan suasana yang nyaman sesuai dengan keinginan pelanggan dan membuat pelanggan ingin berlama-lama berada didalam kedai kopi dan secara tidak langsung merangsang pelanggan untuk melakukan pembelian produk.

Pemasaran merupakan fungsi bisnis yang berhubungan dengan pelanggan. Kesuksesan perusahaan banyak ditentukan oleh prestasi bidang pemasaran dengan mempelajari kebutuhan dan keinginan serta memuaskan pelanggan dengan produk dan pelayanan yang berkualitas sehingga mampu berkompetisi secara kompetitif.

Pada umumnya perusahaan akan membandingkan jumlah penjualan dengan target yang ditentukan dalam mengukur kinerja pemasarannya. Apabila volume penjualan yang di peroleh rendah maka keuntungan dari produk yang dijual akan ikut rendah. Hal ini mempunyai hubungan berbanding lurus antara volume penjualan suatu produk yang di jual dengan pendapatan suatu perusahaan. Demikian halnya dengan keputusan pembelian yang penting dipertahankan guna menjamin bahwa perusahaan mampu berkompetisi dengan baik. Lokasi dan Store Atmosphere sangat berpengaruh untuk pelanggan dalam melakukan keputusan pembelian.
Keputusan pelanggan dalam melakukan pembelian suatu produk merupakan suatu tindakan yang lazim dilakukan oleh setiap individu.

keputusan pembelian merupakan suatu keputusan yang dipengaruhi oleh beberapa faktor yang akan membuat pelanggan secara aktual mempertimbangkan segala sesuatu dan pada akhirnya pelanggan membeli produk tersebut.

Warung Kopi Jaelansky selama ini masih belum mampu memanfaatkan peluang secara optimal, hal ini dilihat dari tidak tercapainya target penjualan dan terus menurunnya jumlah pengunjung. Alasan menurunnya jumlah pengunjung ini bisa diduga karena selain faktor lokasi dan store atmosphere, bisa juga dikarenakan oleh faktor promosi, harga dan juga citra merek dari Warung Kopi Jaelansky sendiri.

diketahui bahwa jumlah pengunjung Warung Kopi Jaelansky tidak pernah mencapai target yang ditentukan. Selama satu tahun terakhir, jumlah pengunjung mengalami penurunan yang cukup signifikan dan hanya pada triwulan kedua jumlah kunjungan meningkat menjadi sebesar $66 \%$, kemudian triwulan berikutnya mengalami penurunan seperti pada triwulan ketiga hanya mencapai $61 \%$ dari yang ditargetkan, kemudian pada triwulan keempat mengalami penurunan lagi menjadi $57 \%$.

Kondisi terkait data pengunjung pada tabel di atas menggambarkan bahwa Warung Kopi Jaelansky harus membenahi kondisi penjualan dengan mengoptimalkan lokasi dan memperbaiki aspek suasana toko guna meningkatkan profit yang ingin dicapai.

Berdasarkan latar belakang diatas dan dengan melihat pentingnya penentuan lokasi dan store atmosphere terhadap keputusan pembelian, maka penulis tertarik untuk membuat penelitian dengan judul "Pengaruh Lokasi dan Store Atmosphere Terhadap Keputusan Pembelian pada Warung Kopi Jaelansky Pamulang". 


\section{TINJAUAN PUSTAKA}

1. Lokasi

Lokasi merupakan salah satu faktor dari situasional yang ikut berpengaruh pada keputusan pembelian. Dalam konsep pemasaran terdapat istilah yang dikenal dengan marketing mix atau bauran pemasaran yang terdiri dari produk, harga, promosi dan place atau lokasi usaha. Dalam marketing mix ini lokasi usaha dapat juga disebut dengan saluran distribusi perusahaan karena lokasi juga berhubungan langsung dengan pembeli atau pelanggan atau dengan kata lain lokasi juga merupakan tempat produsen menyalurkan produknya kepada pelanggan.

Ratih Hurriyati (2015:56) mengemukakan bahwa "tempat (place) diartikan sebagai tempat pelayanan jasa, berhubungan dengan dimana perusahaan harus melakukan operasi atau kegiatannya".

Menurut Heizer \& Render (2015:78) "lokasi adalah pendorong biaya dan pendapatan maka lokasi seringkali memiliki kekuasanaan untuk membuat strategi bisnis perusahaan".

2. Store Atmosphere

Store Atmosphere merupakan salah satu hal yang penting terutama dalam perusahaan penyedia jasa, karena kenyamanan pelanggan merupakan hal yang perlu di utamankan. Dalam hal ini menurut Berman dan Evan (2017:528), "suasana toko meliputi berbagai tampilan interior, eksterior, tata letak, lalu lintas toko, kenyamanan, udara, layanan, music, seragam, penjagaan barang dan sebagainya yang menimbulkaan daya tarik bagi konsumen dan membangkitkan keinginan untuk membeli".

Sedangkan menurut Kotler dan Amstrong (2016:570) "Store Atmosphere merupakan urusan lain dalam persenjataan produk. Setiap toko mempunyai tata letak fisik yang membuat orang bergerak didalamnya dengan susah dan mudah".

3. Keputusan Pembelian

Menurut Tjiptono (2017:21) "keputusan pembelian adalah sebuah proses dimana konsumen mengenal masalahnya, mencari informasi mengenai produk atau merek tertentu dan mengevaluasi seberapa baik masingmasing alternatif tersebut dapat memecahkan masalahnya, yang kemudian mengarah kepada keputusan pembelian"

Menurut Suwarman (2017:377)

"Keputusan Pembelian adalah bagaimana konsumen memutuskan alternatif pilihan yang akan dipilih serta meliputi keputusan mengenai apa yang dibeli, apakah membeli atau tidak, kapan membeli, dimana membeli dan bagaimana cara membayarnya".

\section{METODE PENELITIAN}

Tempat penelitiannya adalah pada Warung Kopi Jaelansky dengan lama waktu penelitian selama 6 bulan.

\section{HASIL DAN PEMBAHASAN}

1. Pengujian Hipotesis

Tabel 1. Pengujian Hipotesis Secara Parsial (Uji t) Hasil Uji t

Coefficients ${ }^{\mathrm{a}}$

\begin{tabular}{|ll|l|l|l|c|c|}
\hline \multirow{2}{*}{ Model } & \multicolumn{2}{|l|}{ Unstandardized Coefficients } & Standardized Coefficients & \multirow{2}{*}{$\mathrm{t}$} & \multirow{2}{*}{ Sig. } \\
\cline { 2 - 5 } & $\mathrm{B}$ & Std. Error & Beta & & 3.585 & .001 \\
\hline 1 & (Constant) & 8,594 & 2,397 & & 6.387 & .000 \\
& X1 & .534 & .084 & .543 & 2.849 & .005 \\
\hline
\end{tabular}

a. Dependent Variable: $Y$

Berdasarkan pengujian hipotesis masing-masing variabel independent terhadap variabel dependent dapat dilihat sebagai berikut: 
a) Uji hipotesis pengaruh lokasi (X1) terhadap keputusan pembelian $(\mathrm{Y})$

Berdasarkan uji t (parsial) hasil pengolahan data untuk lokasi (X1) diperoleh $t_{\text {hitung }}$ sebesar 6,387 dengan nilai signifikasi lebih kecil dari 0,05 yaitu 0,000 . Oleh karena itu, $t_{\text {hitung }}>t_{\text {tabel }}$ yaitu sebesar $6,387>1,985$ atau tingkat signifikan $0,000<0,05$, maka dapat disimpulkan bahwa Ho yang menyatakan lokasi (X1) tidak berpengaruh terhadap keputusan pembelian (Y) ditolak, sedangkan $\mathrm{H}_{1}$ yang menyatakan lokasi (X1) berpengaruh terhadap keputusan pembelian (Y) diterima. Nilai $t_{\text {hitung }}$ positif menunjukkan bahwa lokasi (X1) mempunyai pengaruh yang signifikan terhadap keputusan pembelian (Y).

b) Uji hipotesis pengaruh Store Atmosphere (X2) terhadap keputusan pembelian $(Y)$
Berdasarkan uji $t$ (parsial) hasil pengolahan data untuk store atmosphere (X2) diperoleh $t_{\text {hitung }}$ sebesar 2,849 dengan nilai signifikasi lebih kecil dari 0,05 yaitu 0,005 . Oleh karena itu, $t_{\text {hitung }}>t_{\text {tabel }}$ yaitu sebesar $2,849>1,985$ atau tingkat signifikan 0,005 < 0,05, maka dapat disimpulkan bahwa Ho yang menyatakan Store Atmosphere (X2) tidak berpengaruh terhadap keputusan pembelian $(\mathrm{Y})$ ditolak, sedangkan $\mathrm{H}_{2}$ yang menyatakan Store Atmosphere (X2) berpengaruh terhadap keputusan pembelian (Y) diterima. Nilai thitung positif menunjukkan bahwa Store Atmosphere (X2) mempunyai pengaruh yang signifikan terhadap keputusan pembelian $(Y)$.

2. Pengujian Hipotesis Secara Simultan (Uji F)

Tabel 2. Hasil Uji F

ANOVA $^{\mathrm{a}}$

\begin{tabular}{|ll|l|l|l|l|l|}
\hline \multicolumn{1}{|l|}{ Model } & Sum of Squares & Df & Mean Square & F & Sig. \\
\hline 1 & Regression & 2195,754 & 2 & 1097,877 & 46,089 & $.000^{\mathrm{b}}$ \\
& Residual & 2286,792 & 96 & 23,821 & & \\
\multicolumn{1}{|c|}{ Total } & 4482,545 & 98 & & & \\
\hline
\end{tabular}

a. Dependent Variable: $Y$

b. Predictors: (Constant), X2, X1

Berdasarkan pada hasil pengujian pada tabel di atas diperoleh nilai $F_{\text {hitung }}>\mathrm{F}_{\text {tabel }}$ atau $(46,089>2,700)$, hal ini juga diperkuat dengan $\rho$ value $<$ Sig.0,05 atau $(0,000<0,05)$. Dengan demikian maka $\mathrm{H}_{0}$ ditolak dan $\mathrm{H}_{3}$ diterima, hal ini menunjukkan bahwa terdapat pengaruh yang signifikan secara simultan antara Lokasi (X1) dan Store Atmosphere (X2) terhadap Keputusan Pembelian (Y) pada Warung Kopi Jaelansky Pamulang.

\section{KESIMPULAN}

Berdasarkan pengujian statistik dengan menggunakan uji $\mathrm{t}$ Lokasi (X1) diperolehtingkat signifikansi sebesar 0,000 lebih kecil dari standar signifikansi yang ditetapkan yaitu 0,05 atau 5\%. Dan perbandingan antara thitung dan ttabel dimana thitung sebesar 6,387 lebih besar dari ttabel yaitu 1.985 maka dapat disimpulkan bahwa H0 ditolak dan H1 diterima artinya secara parsial Lokasi (X1) berpengaruh signifikan terhadap Keputusan Pembelian (Y).

Berdasarkan pengujian statistik dengan menggunakan uji $t$ Store Atmosphere (X2) diperoleh tingkat signifikansi sebesar 0,005 lebih kecil dari standar signifikansi yang ditetapkan yaitu 0,05 atau $5 \%$. Dan perbandingan antara thitung dan ttabel dimana thitung sebesar 2,849 lebih besar dari ttabel yaitu 1,985 maka dapat disimpulkan bahwa $\mathrm{H} 0$ ditolak dan $\mathrm{H} 2$ diterima artinya secara parsial Store Atmosphere (X2) berpengaruh signifikan terhadap Keputusan Pembelian (Y).

Berdasarkan pengujian statistik dengan menggunakan uji F Lokasi (X1) dan Store Atmosphere (X2) diperoleh tingkat signifikansi sebesar 0,000 lebih kecil dari standar signifikansi yang ditetapkan yaitu 0,05 atau $5 \%$. Dan perbandingan antara Fhitung dan Ftabel dimana Fhitung sebesar 
46,089 lebih besar dari Ftabel yaitu 2,700 maka dapat disimpulkan bahwa $\mathrm{H} 0$ ditolak dan $\mathrm{H} 3$ diterima artinya secara simultan Lokasi (X1) dan Store Atmosphere (X2) berpengaruh signifikan terhadap Keputusan Pembelian (Y). Nilai koefisien determinasi (R2) atau pengaruh secara simultan adalah sebesar 0,490 atau 49,0\% sedangkan sisanya $51,0 \%$ dipengaruhi oleh variabel lain diluar penelitian

\section{DAFTAR PUSTAKA}

Algifari. (2015). Analisis Regresi Untuk Bisnis Dan Ekonomi. Yogyakarta: BPEE.

Alma, B. (2017). Manajemen Pemasaran dan Pemasaran jasa. Bandung: Alfabeta.

Arikunto, S. (2014). Prosedur Penelitian Suatu Pendekatan Praktis. Jakarta: Rineka Cipta.

Arikunto, S. (2015). Dasar-Dasar Evaluasi Pendidikan. Jakarta: Bumi Akasara.

Ariyanto, A., Nuryani, A., \& Sunarsi, D. (2020). Pengaruh Store Atmosphere Dan Promosi Terhadap Keputusan Pembelian Pada Alfamart BSD Tangerang Selatan. Jurnal Ekonomi Efektif, 3(1).

Badeni. (2016). Kepemimpinan dan Perilaku Organisasi. Bandung: Alfabeta.

Barry, B., \& Joel R. Evans. (2017). Retail Management, $12^{\text {th }}$ edition. New Jersey: Pearson Education Limited 2017.

Christinto, I, M, D., \& Hadi, M. (2018). Jurnal Aplikasi Bisnis, ISSN: 24073741 Vol.4 No.2, Pengaruh Store Atmosphere dan Promosi Terhadap Keputusan Pembelian Pada Gramedia Matos Malang.

Erlangga, H. (2020). The Challenges of Organizational Communication in the Digital Era. Solid State Technology, 63(4), 1240-1246.

Fikri, M. Z., \& Mulazid, A, S. (2018). Jurnal Syarikah, ISSN: 2528-6935 Vol.4 No.1, Pengaruh Brand Image, Lokasi dan Store Atmosphere Terhadap Proses Keputusan Pembelian Pada Minimarket "Kedai Yatim".

George R. Terry., \& Leslie W. Rue. (2017). Dasar-Dasar Manajemen. Jakarta: PT Bumi Aksara.
Ghozali. (2017). Aplikasi Analisis Multivariate dengan Program SPSS, Edisi Kelima. Semarang: Universitas Diponegoro.

Handoko, T, H. (2016). Manajemen Edisi 2. Yogyakarta: BPFE.

Haque, MG., Munawaroh, Sunarsi, D., (2020). Analysis of SMEs Culinary Marketing Strategy During Covid 19 Pancemic: A Study at "Sate Bebek Cilegon" Resto in Cilegon, Banten. International Journal of Education, Information Technology, and Others. Vol.3. Issue 2

Hartuti, E, T, K., \& Manik, C, D. (2020). Jurnal Administrare: Jurnal Pemikiran Ilmiah dan Pendidikan Administrasi Perkantoran, ISSN: 2407-1765 Vol.7 No.1, Analisis Pengaruh Persepsi Konsumen, Inovasi, dan Kualitas Produk terhadap Keputusan Pembelian Wisatawan yang Mengonsumsi Makanan Tradisional Getuk Goreng di Jawa Tengah.

Hasan, A. (2017). Marketing Dan Kasus-Kasis Pilihan. Yogyakarta: CAPS.

Hasibuan. (2016). Manajemen Sumber Daya Manusia, Edisi Revisi. Jakarta: PT Bumi Aksara.

Heizer, J., \& Render, B. (2015). Manajemen Operasi: Manajemen Keberlangsungan dan Rantai Pasokan, Edisi 11. Jakarta: Salemba Empat.

Hurriyati, R. (2015). Bauran Pemasaran dan Loyalitas Konsumen. Bandung: Alfabeta.

Istijanto. (2014). Riset Sumber Daya Manusia. Jakarta: Gramedia Pustaka.

Jasmani, J., Sutiman, S., \& Sunarsi, D. (2020). Analysis of the Effect of Prices, Promotions and Products on Purchase Interest Impacts on Consumer Satisfaction of VIVO Brand Mobile Phones in South Tangerang Region. Jurnal Ad'ministrare, 7(1), 73-82.

Kasmad, K., Mustakim, M., \& Sunarsi, D. (2020). Increasing Community School Interest Through Service Quality, Prices and Promotion in Vocational High Schools. Journal of Educational Science and Technology (EST), 6(2). 
Katarika, D, M., \& Syahputra. (2017). Jurnal Ecodemica, ISSN: 2355-0295 Vol.1 No.2, Pengaruh Store Atmosphere Terhadap Keputusan Pembelian pada Coffee Shop di Bandung.

Kotler, P., \& Amstrong, G. (2016). Principle Of Marketing, 15th Edition. New Jersey:Pearson Pretice Hall.

Kotler, P., \& Keller, K, L. (2017). Marketing Management, $15^{\text {th }}$ Edition. England: Pearson Edication.

Lamb et al, C. (2017). Pemasaran. Jakarta: Salemba Empat.

Maddinsyah, A., Hidayat, D., Juhaeri, J., Susanto, D., \& Sunarsi, D. (2020). Desain Formulasi Dan Implementasi Bisnis Strategik Dengan Pendekatan Business Model Canvas (BMC) Terintegrasi Kerangka Integrated Performance Management System (IPMS) Pada Koperasi Asperindo. Inovasi, 7(2), 67-76

Mas'adi, M. (2020). Pengaruh Kegiatan Promosi Terhadap Keputusan Pembeian Pada PT. Indotex Mandiri di Tangerang. Jurnal Ekonomi efektif, 3(1).

Oentoro, D. (2016). Manajemen Pemasaran Modern. Yogyakarta:LakBang PRESSindo.

Santoso, S. (2015). Menguasai Statistik Multivariat. Jakarta:PT Elex Media Komputindo.

Siregar, S. (2015). Metode penelitian kuantitatif: dilengkapi dengan perbandingan perhitungan manual dan spss. Jakarta: Kencana.

Sobarna, A., Rizal, R. M., Hambali, S., \& Sunarsi, D. (2020). Influence Make a Match Model toward Communication skills in Physical and Health Pedagogical Concept. Solid State Technology, 63(6), 1355-1363.

Sudjana, N. (2014). Penilaian Hasil Proses Belajar Mengajar. Bandung: PT Remaja Rosdakarya.

Sugiyono. (2017). Metode Penelitian Pendidikan Pendekatan Kuantitatif, Kualitatif, dan R\&D". Bandung: Alfabeta.
Sukmaningtyas, M., Rulirianto. (2019). Jurnal Aplikasi Bisnis, ISSN: 24073741 Vol.5 No.1, Pengaruh Lokasi dan Store Atmosphere (Suasana Toko) Terhadap Keputusan Pembelian di Warkop Brewok II Kota Malang.

Sunarsi, D. (2020). Pengaruh Bauran Pemasaran Dan Kualitas Pelayanan Terhadap Kepuasan Konsumen Pada Giant Dept Store Cabang BSD Tangerang. E-Mabis: Jurnal Ekonomi Manajemen dan Bisnis, 21(1).

Sunyoto, D. (2016). Dasar-Dasar Manajemen

Pemasaran, Catatan Pertama. Yogyakarta: CAPS.

Supangat, A. (2015). Statistik Dalam Kajian Deskriptif, Inferensi dan Nonparametik. Jakarta: Kencana Prenada Media Group.

Suwarman, U. (2017). Riset Pemasaran Dan Konsumen. Jakarta: Salemba Empat.

Syobar, K., Hardiyan, A., Romlah, O. Y., Yusup, M., \& Sunarsi, D. (2020). The Effect of Service Quality and Price on Purchase Decisions in Woodpecker Coffee in South Jakarta. Solid State Technology, 63(6), 1491-1504.

Thamrin, A., \& Tantri, F. (2016). Manajemen Pemasaran. Depok: PT Raja Grafindo Persada.

Tjiptono, F. (2015). Strategi Pemasaran, Edisi 4.Yogyakarta: Andi.

Tjiptono, F. (2017). Pemasaran Strategik, Edisi 2.Yogyakarta: Andi.

Usti, F. (2018). Indonesian Jurnal Of Strategic Management, ISSN: 26145391 Vol.1, Pengaruh Store Atmosphere Terhadap Keputusan Pembelian Konsumen Pada Toserba Terbit Kuningan.

Wahyuningtias, R. (2017). Jurnal Ilmu dan Riset Manajemen, ISSN: 2461-0593 Vol.6 No.3, Pengaruh Kualitas Produk, Harga dan Store Atmosphere Terhadap Keputusan Pembelian.

Yusuf, A., \& Sunarsi, D. (2020). The Effect of Promotion and Price on Purchase Decisions. Almana: Jurnal Manajemen dan Bisnis, 4(2), 272-279. 